\title{
ЧЕЛОВЕЧНОСТЬ И КРЕАТИВНОСТЬ В НРАВСТВЕННОМ РАЗВИТИИ МОЛОДЕЖИ
}

\author{
Наталья Г. Брюхова", Светлана В. Агафонова \\ Астраханский государственный университет, г. Астрахань, \\ Российская Федерация \\ *E-mail: bryukhova@list.ru
}

Статья посвящена решению проблемы преодоления нравственного кризиса в современном обществе путем исследования особенностей развития у молодых людей человечности и креативности в прочессе нравственного развития. Человечность рассматривается как проявление нравственности.

В статье показано, что признаки самоактуализирующейся личности с позиций зарубежной гуманистической психологии не во всем соответствуют требованиям, предъявляемым к нравственной личности с позиций отечественной психологии. Авторами статьи проанализированы и продемонстрированы различия в подходах к рассмотрению понятий «человечность» и «креативность» с данных позиций.

Представлены результаты эмпирического исследования, выполненного в течение 2012-2016 г2. на выборке объемом 992 человека. Выявлено, что у молодых людей человечность и креативность развиты на среднем уровне. При этом у обучающихся и начинающих специалистов психолого-педагогического направления (особенно у девушек), в сравнении с другими выборками, слабо развиты как функции «добра», так изла». Следовательно, для формирования профессионально значимых качеств будущих педагогов и психологов необходимо особые усилия направлять на их нравственное развитие, на обучение их совершению нравственного выбора между добром и злом.

Получены данные об отрицательной коррелячии у молодежи креативности как проявления самоактуализации с «добром» и «коэффициентом человечности», и положительной коррелячии со «злом». Развитие креативности у молодежи приводит к снижению уровня ее нравственного развития по показателю человечности.

В статье на основании проведенного теоретического анализа и маситабного эмпирического исследования взаимосвязи развития человечности и креативности обоснована необходимость критического отношения к положениям зарубежной гуманистической психологии в части их противоречия реализачии человеком в ходе своей жизнедеятельности непреходящих общечеловеческих нравственных принципов и норм. 
В прочессе сопровождения личностного развития молодежи необходимо формировать у молодых людей умение оценивать происходящее по критериям человечности как проявления нравственности, основывающейся на непреходящих общечеловеческих принципах.

Ключевые слова: человечность, добро, зло, гуманистическая психология, креативность, творчество, самоактуализирующаяся личность, нравственное развитие, нравственный выбор, молодежь.

Для цитирования: Брюхова Н. Г., Агафонова С. В. Человечность и креативность в нравственном развитии молодежи // Российский психологический журнал. - 2017. - Т. 14. - № 1. - С. 39-61.

Материалы статьи получены 31.07.2016

UDC 159.923.2

doi: 10.21702/rpj.2017.1.3

\title{
HUMANENESS AND CREATIVITY IN THE MORAL DEVELOPMENT OF YOUNG PEOPLE
}

\author{
Natal'ya G. Bryukhova*, Svetlana V. Agafonova \\ Astrakhan State University, Astrakhan, Russian Federation \\ *Correspondence author. E-mail: bryukhova@list.ru
}

Humaneness is a manifestation of morals. The present paper discusses the problem of overcoming moral crisis in modern society and analyses the development of humaneness and creativity in the moral development of young people.

Features of self-actualizing personality in foreign humanistic psychology do not correspond to the concept of moral personality in domestic psychology. The analysis demonstrated differences in approaches to the concepts of "humaneness" and "creativity".

The empirical study carried out in 2012-2016 involved 992 persons. The obtained results revealed average levels of young people's humaneness and creativity. Moreover, psychology and pedagogy students and young experts (especially girls) had lower rates of "good" and "evil" functions than respondents in other samples. Hence, moral development and a moral choice between good and evil are especially important in the formation of professionally significant qualities of future pedagogues and psychologists.

The data showed (a) the negative correlation among creativity, "good", and "humaneness factor", (b) the positive correlation between creativity and "evil". The development of young people's creativity decreases the level of moral development by the factor of humaneness. 
The theoretical analysis and the findings from the empirical study of the association between humaneness and creativity established the necessity of critical understanding of foreign humanistic psychological propositions, because of their contradiction with the person's realization of enduring universal moral principles and norms.

The formation of the ability to assess what is going on according to the criteria of humaneness is required to support the personal development of young people.

Keywords: humaneness, good, evil, humanistic psychology, creativity, selfactualizing personality, moral development, moral choice, young people.

For citation: Bryukhova N. G., Agafonova S. V. Humaneness and creativity in the moral development of young people. Rossiiskii psikhologicheskii zhurnal - Russian Psychological Journal, 2017, V. 14, no. 1, pp. 39-61 (in Russian).

Original manuscript received 31.07.2016

\section{Введение в проблему}

Существующий в современном обществе кризис морали, как справедливо отмечает Е. К. Веселова, «выражается в "размывании" основных нравственных норм, существовавших около двух тысячелетий и составлявших ядро большинства моральных кодексов прошлого» [9, с. 92]. «В наше смутное время может исчезнуть и, выражаясь словами А. Н. Леонтьева, "человечный человек"» [15, с. 187], поскольку «на авансцену российской социально-политической и экономической жизни выходят "дети 90-х" - поколение, воспитанное в годы разрушения традиционных морально-этических устоев» [20, с. 5]. По данным А. В. Юревича и Д. В. Ушакова, современная молодежь в ходе опросов социологов и психологов «часто отвечает, что вообще не использует такие понятия, как добро и зло, хорошее и плохое, предпочитая им категории "круто - не круто" и т. п., и, встречая в формулировках вопросов слово "нравственное", нередко спрашивает, что оно означает» [27, с. 183-184]. В связи с этим авторы говорят о необходимости воспитывать у молодежи понимание того, что стирание границ между добром и злом, «толерантность к злу и смирение перед ним, способствует его утверждению во все более бесчеловечных формах» [27, с. 180-181], что может привести к необратимым последствиям. Именно поэтому в послании президента России В. В. Путина к Федеральному Собранию в 2012 г. «О духовно нравственном и военно-патриотическом воспитании детей и молодежи» указывается на необходимость возрождения в умах и сердцах молодых людей морально-нравственных ориентиров.

С. Л. Рубинштейн отмечает, что «моральное отношение к человеку - это любовное отношение к нему. Любовь выступает как утверждение бытия 
человека. Лишь через свое отношение к другому человеку человек существует как человек» [23, с. 373]. «Человечность человека проявляется в его отношении к другому, отношение к другому должно быть таким же, как к самому себе» [23, с. 377]. Так классик отечественной психологии вторит Евангелиевским призывам: «И так во всем, как вы хотите, чтобы с вами поступали люди, так поступайте и вы с ними, ибо в этом закон и пророки» (Евангелие от Матфея, 7:12).

Многочисленными отечественными исследователями подтверждается, что использование «золотого правила» - «поступай с другими так, как ты бы хотел, чтобы поступали с тобой» - помогает разобраться в сложных ситуациях, различить добро и зло, сделать положительный нравственный выбор [2].

Нравственность является одним из наиболее важных, первостепеннейших аспектов и ориентиров жизненного пути человека [7]. «Высоконравственный жизненный путь есть результат осознанного выбора, жизненного и нравственного самоопределения человека» [13, с. 233].

Нравственное развитие - это процесс присвоения моральных норм, их обобщения и «превращения во внутренние "моральные инстанции", реализуемые поведением» [18, с. 25]. Уровень нравственного развития человека отражает уникальный сплав нравственных характеристик, располагающихся в определенной динамике между полюсами добра и зла, образованными разнообразными этически-конструктивными и этически-деструктивными качествами личности. К этически-конструктивным образованиям относятся честность, гуманизм, ответственность, доверие, бескорыстие, самопожертвование и т. п. Этически-деструктивными образованиями являются жестокость, цинизм, эгоизм, беспринципность и т. п. [24].

Таким образом, в процессе нравственного развития человека происходит усвоение нравственных норм, в результате которого он становится добрее, человечнее.

В наиболее разработанной в рамках отечественной психологии концепции человечности В. Д. Шадрикова человечность рассматривается как главное, особое, сущностное, отличительное качество человека, развивающегося человечества, воплощаемое в индивидуальности конкретного человека. Человечность определяется «как путь развития от телесного к душевному и далее, к духовному» [26, с. 70], как характеристика человека в его отношениях с другими людьми, как не слова, а поступки, которые нужно интерпретировать в категориях морали. Автор считает, что «мораль рождается одновременно с религией и равна ей по объему» [26, с. 161]. Добро и зло являются основными характеристиками человечности. Человечность по своей природе амбивалентна, т. к. «в ней присутствует добро и зло, любовь и ненависть» [26, с. 97]. В человеке происходит осознанная борьба 
двух начал: «добра и зла, эгоизма и альтруизма» [26, с. 103]. «Человечность выступает как победа добра над злом в конкретном поступке и во всем складе личности» [26, с. 110]. Одним из высших проявлений человечности является любовь, развитая от уровня «биологического влечения до высших форм своего выражения - любви как проявления человечности» [26, с. 138].

Л. М. Попов вносит важные уточнения в представления о человечности: это «ориентация в деяниях в большей степени на добро (милосердие, свобода, совесть, счастье и т. д.), чем на зло (агрессия, тщеславие, насилие, грубость и т. д.)» [19, с. 14]; «интегративная характеристика этического слоя личности» $[19$, с. 136]; «степень преобладания конструктивного начала над этически деструктивным» [19, с. 145].

Человечность проявляется в готовности оказывать помощь другим людям, готовности к самопожертвованию [3].

Для обладания человеком человечностью, как минимум, надо жить в соответствии с естественным нравственным законом, основным нравственным «ядром которого являются десять заповедей Моисея» [9, с. 92]. Обретению человечности содействует приобщение человека к высшим духовно-нравственным ценностям человечества. «Если человек эмоционально глух, а высшие человеческие ценности ему чужды, то чем "компетентнее" он во всех прочих отношениях, тем опаснее для общества и для себя самого» [14, с. 283].

Таким образом, мы видим, что в рамках отечественного мировоззрения, отечественной парадигмы человечность есть проявление нравственности, основой которой является следование фундаментальным религиозным общечеловеческим принципам. В человечности выражается то, насколько добро превышает зло в человеке, в людях, в человечестве.

В переводе на английский язык «человечность» обозначается такими словами, как humanity, humanness, humaneness, humanism, и означает «гуманизм», «гуманность».

Таким образом, эти понятия обращают наше внимание к гуманистическому подходу в психологии. В современных зарубежных исследованиях, посвященных различным проблемам гуманистической психологии, акцентируется внимание на таких гуманистических ценностях, как:

- достоинство человеческой личности, познание и понимание которой осуществляется посредством любви [37];

- подлинность или идентичность, освещаемая в связи со стилями юмора [29];

- счастье, рассматриваемое как феномен [32] и обусловленное ощущением личностной уникальности [34];

- благополучие как удовлетворение потребностей в основных областях жизни и социальная справедливость $[30,35]$. 
На наш взгляд, из числа последних работ в наибольшей мере к обсуждению темы человечности приближает, обозначенное как проблема, противоречие между разнообразием людей и общностью человечества [33].

Известно, что в рамках зарубежных исканий понятие «человечность» является наиболее разработанным в концепции самоактуализирующейся личности А. Г. Маслоу и К. Р. Роджерса. Но, как справедливо отмечают А. Деркач и В. Зазыкин, основатель гуманистической психологии в характеристике самого дорогого для него - самоактуализирующейся личности - не отметил ее именно гуманистической, т. е. человеческой направленности. Получается, что «такая личность развивается только для себя, с ориентацией только на себя» [4, с. 20-21]. То есть, самоактуализирующаяся личность - эгоцентрическая личность.

Сходной позиции придерживается и В. Э. Франкл, который подмечает, что по А. Маслоу «окружающий мир является не более чем средством для самореализации» [36, с. 117]. В. Э. Франкл утверждает, что «самореализация - это следствие, и она не может быть объектом стремления» [31, с. 40], и что «поскольку самореализация предполагает использование доступных возможностей, или потенций внутри субъекта, это можно назвать потенциализмом». В. Э. Франкл полагает, что вызов любой жизненной ситуации - это вызов ответственности, а «потенциализм пытается избежать этого бремени ответственности» [25, с. 40-52].

Мы согласны с В. Э. Франклом в том, что самореализация - это следствие, результат, и она не должна быть объектом стремления.

Действительно, нельзя считать гуманной провокацию основоположников классического гуманистического консультирования «к действию без оценки последствий и принятия ответственности за эти действия» [21, с. 143]. Подтверждением вышесказанному может служить контент-анализ текстов (и контекстов) большинства монографий основоположников зарубежной гуманистической психологии, в которых теме человечности как атрибута «нравственности уделяется (если и уделяется) сравнительно минимальное внимание» [8, с. 298].

Самотрансценденция является одним из существенных качеств человеческого бытия. Только когда человек выходит за пределы себя самого и перестает концентрировать свой интерес, свое внимание исключительно на себе самом, он достигает аутентичного бытия [5, 23, 25].

А. Маслоу считает понятие «человечность» двойственным, и что «добро» есть мера «исполнения чем-либо (или кем-либо) своего предназначения, как степень воплощения заложенной в нем идеи» [17, с. 41]. Вводя и разводя понятия «вочеловеченность» и «недочеловечность», А. Г. Маслоу определяет последнее как «явление утраты или недостаточной актуализации человеком своих способностей и возможностей» [17, с. 43]. Он пишет, что «вместо 
таких понятий, как "незрелость”, “несчастье”, “болезнь”, “врожденные дефекты”, “обделенность", мы можем говорить о “недочеловечности"» [17, с. 295]. Таким образом, мы видим, что «недочеловечность» в понимании автора - это скорее недополучение человеком чего-либо от жизни, а не нравственная деградация как результат недостаточной требовательности к самому себе, как в первую очередь подумали бы многие из нас.

А. Г. Маслоу указывает на близкую взаимосвязь понятий «вочеловеченности» как самореализованности и креативности [17]. Представителями гуманистической психологии креативность определяется как «стремление к творчеству, творческое отношение к жизни» [16, с. 298], «способность к творчеству» $[22$, с. 74], «способность искать и находить новые способы решения проблем и новые способы самовыражения» [22, с. 79]. К. Роджерс утверждает, что креативная личность - это личность, которая выступает в качестве авангарда человеческой эволюции, успешно приспосабливается, выживает и творчески адаптируется «как к новым, так и к старым условиям» [38, с. 290]. А. Г. Маслоу обещает через проявления креативности достижение пиковых переживаний блаженства, восторга, экстаза [17].

Проведя анализ методики по оценке уровня самоактуализации личности, разработанного в рамках концепции А. Маслоу и К. Роджерса, мы обнаружили, что шкала, предназначенная для выявления творческого подхода к выполнению разных видов деятельности, выявляет стремление к творчеству ради получения удовольствия в противовес получению общественно ценного результата или продукта.

Ряд отечественных и зарубежных ученых рассматривает понятие «креативность» и «творчество» как синонимичные [1]. Другие авторы утверждают, что «креативность» является способностью личности, а «творчество» - характеристикой деятельности [12]. По Е. П. Ильину, чью позицию мы разделяем, креативность - это интегральная способность «человека порождать необычные идеи, находить оригинальные решения, отклоняться от традиционных схем мышления» [14, с. 157], определяющая творческий характер его деятельности.

Психологическую основу креативной способности составляет дивергентное, идущее одновременно в разных направлениях, отступающее от логики, мышление [6]. Подчеркивается, что «креативные решения требуют широких знаний в определенной области» [14, с. 201], для накопления которых требуется, как правило, не менее десяти лет.

В связи с вышесказанным примечательна взаимосвязь между человечностью, духовностью и творчеством, отмеченная В. Д. Шадриковым: «ведущей действующей силой становления человечности является духовность». «Вершиной творческой деятельности становятся духовные творения человека, в которых делается попытка осмыслить роль и назначение человека 
в истории, его отношения с другими людьми с позиций добра и зла. В этом творческом поиске формируется духовность человека как высшее проявление человечности» [26, с. 69-70].

Высоконравственная личность ради других людей и общества в целом проявляет свой творческий потенциал, но в выборе нравственных способов решения задач и проблем, воздействия и влияния, оказания помощи другим людям [13].

Таким образом, мы видим, что в рамках зарубежной гуманистической психологии креативность, в своем максимальном проявлении, - есть показатель соответствия человека требованиям, предъявляемым озабоченной полнотой самореализации самоактуализирующейся личности. В отечественной психологической традиции подчеркивается необходимость развития креативности как активного созидательного начала.

В ряде проведенных исследований были выявлены отрицательные связи человечности с характеристиками самоактуализирующейся личности. Так, в выборке с высокими показателями циничности (группа циников) была выявлена отрицательная корреляционная связь «человечности» с такой характеристикой самоактуализации личности (использовался тест «САТ» [11]), как «компетентность во времени» «в выборке с высоким показателем циничности» [19, с. 141]. Было выявлено, что у выборок молодежи - будущих психологов и педагогов - «человечность» коррелирует значимо отрицательно с «самопониманием» как атрибутом самоактуализирующейся личности. То есть, развитие понимания молодыми людьми себя самоактуализирующимися «не предполагает нравственного развития личности, а порой, по сути, ведет к нравственной деградации» [8, с. 298]. Как мы видим, эти эмпирические данные дают повод усомниться в нравственной направленности личности, стремящейся к самоактуализации.

Молодость (от 17-18 до 25-29 лет) является периодом духовно-нравственного самоопределения [10]. Предыдущие исследования авторов статьи показали, что процесс профессионального обучения молодежи должен быть обусловлен ее нравственным развитием [28].

В современном обществе, в том числе и среди молодых людей, креативность считается положительным качеством человека, обеспечивающим эффективность деятельности. Создаются условия для стимулирования развития креативности у молодежи: организуются конкурсы, в которых требуется представить оригинальные проекты или результаты; работодатели нередко называют это качество как одно из требований при профессиональном отборе претендентов на работу и др.

С целью изучения особенностей развития у молодых людей качеств человечности в рамках их нравственного развития и связей этих качеств 
с развитием креативности (в понимании гуманистической психологии) нами было предпринято эмпирическое исследование.

\section{Методы исследования}

Для исследования были использованы следующие психодиагностические методики: психодиагностический тест Л. М. Попова «Добро и зло» [19] для выявления уровней развития личностных черт по функциям «добра» и «зла», и «коэффициента человечности» как ориентации в большей степени на добро, чем на зло; шкала «креативность» как стремление к творчеству или творческое отношение к жизни теста «САМОАЛ» по оценке уровня самоактуализации личности (адаптация Н. Ф. Калиной и А. В. Лазукиным вопросника Э. Шострем POI (Personal Orientation Inventory), разработанного ею в рамках концепции А. Маслоу и К. Роджерса) [16].

В исследовании приняли участие студенты и начинающие специалисты, обучающиеся и обучавшиеся с 2012 по 2016 гг. в Астраханском государственном университете (АГУ) и в Астраханском государственном техническом университете (АГТУ), общей численностью 992 человека. Из них по 248 человек в четырех подгруппах: 1) обучающиеся и начинающие специалисты психолого-педагогического направления (девушки); 2) обучающиеся и начинающие специалисты психолого-педагогического направления (юноши); 3) обучающиеся по другим направлениям подготовки (девушки); 4) обучающиеся по другим направлениям подготовки (юноши).

\section{Результаты}

Анализ процентных показателей количества молодежи, характеризующейся разными уровнями развития «добра» как черты личности, позволил сделать вывод о том, что среди обучающихся и работающих молодых людей не выявлены те, которые характеризуются высоким уровнем развития «добра» (таблица 1). С уровнем «добра» как черты личности выше среднего и средним уровнем (15\% и $41 \%$ соответственно от данной части выборки) максимальное количество лиц среди юношей, обучающихся по другим направлениям подготовки, а минимальное количество - среди девушек, обучающихся и начинающих специалистов психолого-педагогического направления (5\% и $15 \%$ соответственно от данной части выборки).

Наибольшее количество лиц с уровнем развития «добра» ниже среднего выявлен у девушек - обучающихся и начинающих специалистов психологопедагогического направления (62\% от этой части выборки). Низкий уровень развития «добра» чаще встречается у юношей - обучающихся и начинающих специалистов психолого-педагогического направления (63\% от этой части выборки). 
Таблица 1.

Процентные показатели количества молодых людей, характеризующихся разными уровнями развития «добра» как черты личности (\%)

Table 1.

Percentage distribution of young people with various levels of "good" as

a personality trait (\%)

\begin{tabular}{|c|c|c|c|c|c|}
\hline $\begin{array}{r}\text { Уровни развития } \\
\text { "добра" } \\
\text { Levels of "Good" } \\
\text { Bыборки } \\
\text { Samples }\end{array}$ & $\begin{array}{c}\text { Низкий } \\
\text { Low }\end{array}$ & $\begin{array}{c}\text { Ниже } \\
\text { среднего } \\
\text { Below } \\
\text { Average }\end{array}$ & $\begin{array}{l}\text { Средний } \\
\text { Average }\end{array}$ & $\begin{array}{c}\text { Bыule } \\
\text { среднего } \\
\text { Above } \\
\text { Average }\end{array}$ & $\begin{array}{c}\text { Высокий } \\
\text { High }\end{array}$ \\
\hline $\begin{array}{l}\text { Обучающиеся и начина- } \\
\text { ющие специалисты пси- } \\
\text { холого-педагогического } \\
\text { направления (девушки) } \\
\text { Psychology and pedagogy } \\
\text { students and young } \\
\text { experts (girls) }\end{array}$ & 18 & 62 & 15 & 5 & 0 \\
\hline $\begin{array}{l}\text { Обучающиеся и начина- } \\
\text { ющие специалисты пси- } \\
\text { холого-педагогического } \\
\text { направления (юноши) } \\
\text { Psychology and pedagogy } \\
\text { students and young } \\
\text { experts (young men) }\end{array}$ & 63 & 5 & 23 & 9 & 0 \\
\hline $\begin{array}{l}\text { Обучающиеся по другим } \\
\text { направлениям подготов- } \\
\text { ки (девушки) } \\
\text { Students in other } \\
\text { disciplines (girls) }\end{array}$ & 36 & 24 & 31 & 9 & 0 \\
\hline $\begin{array}{l}\text { Обучающиеся по другим } \\
\text { направлениям подготов- } \\
\text { ки (юноши) } \\
\text { Students in other } \\
\text { disciplines (young men) }\end{array}$ & 33 & 11 & 41 & 15 & 0 \\
\hline
\end{tabular}


Получается, что сниженный уровень развития «добра» (ниже среднего и низкий) характерен для 3-х групп испытуемых в порядке убывания:

1) обучающиеся и начинающие специалисты психолого-педагогического направления (девушки) - $80 \%$;

2) обучающиеся и начинающие специалисты психолого-педагогического направления (юноши) - 68\%;

3) обучающиеся по другим направлениям подготовки (девушки) - $60 \%$.

Причем, как видно, доля молодых людей со сниженным уровнем развития «добра» как черты личности является преобладающей - от более чем половины выборки до 4/5 ее части. Такие результаты свидетельствуют о том, что современные молодые люди воспитывались и развивались без ориентации на общечеловеческие непреходящие ценности добра. Самое интересное и вместе с тем печальное, что результаты по данному показателю тем ниже, чем выше ожидается развитие данного качества у определенной категории людей. А именно, самый худший этот показатель для обучающихся и начинающих специалистов гуманистических профессий - педагогов и психологов, к тому же он намного хуже у девушек по сравнению с юношами.

Парадоксально, что наименьшие, т. е. лучшие, значения по этому показателю выявлены у юношей, обучающихся по другим направлениям подготовки (44\%). Из полученных данных напрашивается вывод о том, что для молодых людей, избравших свой профессиональный путь в области психолого-педагогического направления, в большей мере значимо, чтобы их собственное развитие осуществлялось на основе нравственных ценностей. Иначе без этого у них не формируются профессионально значимые личностные качества, необходимые специалистам системы профессий «человек - человек», и в первую очередь педагогам и психологам.

Процентные показатели количества молодых людей, характеризующихся разными уровнями развития черт личности по функции «зла», позволили сделать вывод о том, что только среди девушек, обучающихся и начинающих специалистов психолого-педагогического направления, нет тех, которые бы характеризовались высоким уровнем «зла» (таблица 2). В остальных выборках количество молодежи с высоким уровнем развития «зла» не превышает 3-4\%.

Наибольшее количество лиц с уровнем развития черт личности по функции «зла» выше среднего среди юношей и девушек, обучающихся по другим направлениям подготовки - $26 \%$ и $23 \%$ соответственно, что составляет относительно небольшую часть - около 1/4 - данных выборок.

Наибольшее количество лиц со сниженным уровнем развития черт личности по функции «зла» (ниже среднего и низким) у представителей психолого-педагогического направления: у девушек - $84 \%$, у юношей - 73\%. Это составляет преобладающую часть данных групп выборок. 
Таблица 2.

Процентные показатели количества молодых людей, характеризующихся разными уровнями развития черт личности по функции «зла» (\%)

Table 2.

Percentage distribution of young people with various levels of personal traits by the "evil" function (\%)

\begin{tabular}{|c|c|c|c|c|c|}
\hline $\begin{array}{l}\text { Уровни paзвития "зла»" } \\
\text { Levels of "Evil" } \\
\text { Bыборки } \\
\text { Samples }\end{array}$ & $\begin{array}{c}\text { Низкий } \\
\text { Low }\end{array}$ & $\begin{array}{c}\text { Ниже } \\
\text { среднего } \\
\text { Below } \\
\text { Average }\end{array}$ & $\begin{array}{l}\text { Средний } \\
\text { Average }\end{array}$ & $\begin{array}{c}\text { Bыше } \\
\text { среднего } \\
\text { Above } \\
\text { Average }\end{array}$ & $\begin{array}{c}\text { Высокий } \\
\text { High }\end{array}$ \\
\hline $\begin{array}{l}\text { Обучающиеся и начина- } \\
\text { ющие специалисты пси- } \\
\text { холого-педагогического } \\
\text { направления (девушки) } \\
\text { Psychology and pedagogy } \\
\text { students and young } \\
\text { experts (girls) }\end{array}$ & 57 & 27 & 14 & 2 & 0 \\
\hline $\begin{array}{l}\text { Обучающиеся и начина- } \\
\text { ющие специалисты пси- } \\
\text { холого-педагогического } \\
\text { направления (юноши) } \\
\text { Psychology and pedagogy } \\
\text { students and young } \\
\text { experts (young men) }\end{array}$ & 56 & 17 & 11 & 13 & 3 \\
\hline $\begin{array}{l}\text { Обучающиеся по другим } \\
\text { направлениям подготов- } \\
\text { ки (девушки) } \\
\text { Students in other } \\
\text { disciplines (girls) }\end{array}$ & 28 & 28 & 17 & 23 & 4 \\
\hline $\begin{array}{l}\text { Обучающиеся по другим } \\
\text { направлениям подготов- } \\
\text { ки (юноши) } \\
\text { Students in other } \\
\text { disciplines (young men) }\end{array}$ & 30 & 26 & 15 & 26 & 3 \\
\hline
\end{tabular}


Таким образом, мы видим, что количество юношей и девушек, обучающихся и начинающих специалистов психолого-педагогического направления, в сравнении с юношами и девушками, обучающихся по другим направлениям подготовки, значительно больше как с низким уровнем развития «добра», так и с низким уровнем развития «зла». Это свидетельствует о том, что данные молодые люди проявляют равнодушие в вопросах оценки добра и зла, и значит, они еще не сделали ни положительного, ни отрицательного нравственного выбора. А совершение личностного выбора является механизмом развития человека и продвижения к его достижению зрелости. По высказыванию А. Г. Асмолова: «Быть личностью - это значит осуществлять выборы, возникшие в силу внутренней необходимости, уметь оценить последствия принятого решения и держать за них ответ перед собой и миром. Быть личностью - это значит обладать свободой выбора и нести через всю жизнь бремя выбора» [5, с. 410].

Таким образом, несовершение нравственного выбора молодыми людьми - будущими и начинающими специалистами психолого-педагогического направления - отрицательно влияет на их личностное развитие. А это означает, что им трудно будет выполнять свою профессиональную функцию по формированию и воспитанию личности подрастающего поколения.

Согласно ключу к методике «Добро и зло» Л. М. Попова, показатели шкалы «коэффициент человечности» вычисляются по формуле: «Добро минус Зло». Выявлено, что молодые люди во всех 4-х группах характеризуются преимущественно средним уровнем развития человечности, и среди девушек и юношей, будущих и начинающих специалистов психолого-педагогического направления, таких больше. При этом среди девушек и юношей, обучающихся по другим направлениям подготовки, больше лиц с коэффициентом человечности выше среднего (таблица 3).

Такие данные подтверждают наши выводы, сделанные нами выше. У девушек и юношей, будущих и начинающих специалистов психолого-педагогического направления (педагоги и психологи), выявлен низкий уровень развития личностных черт по функциям и «добра», и «зла». Ниже среднего уровня развиты личностные особенностей по функции «зла» у девушек и юношей, обучающихся по другим направлениям подготовки. Только у юношей, обучающихся по другим направлениям, уровень развития особенностей характера по функции «добра» средний.

Таким образом, развитие таких качеств личности как доброта и человечность, являющихся выражением нравственности личности, особенно у будущих и начинающих специалистов психолого-педагогического направления, нуждается в пристальном внимании и целенаправленно организованной работе в процессе профессиональной подготовки. 
Таблица 3.

\begin{abstract}
Процентные показатели количества молодых людей, характеризующихся разными уровнями развития человечности (коэффициент человечности) (\%)
\end{abstract}

Table 3.

\title{
Percentage distribution of young people with various levels of
} humaneness (the coefficient of humaneness) (\%)

\begin{tabular}{|c|c|c|c|c|c|}
\hline $\begin{array}{r}\text { Уровни развития } \\
\text { человечности } \\
\text { Levels of } \\
\text { Humaneness }\end{array}$ & $\begin{array}{c}\text { Низкий } \\
\text { Low }\end{array}$ & $\begin{array}{c}\text { Ниже } \\
\text { среднего } \\
\text { Below } \\
\text { Average }\end{array}$ & $\begin{array}{l}\text { Cредний } \\
\text { Average }\end{array}$ & $\begin{array}{c}\text { Bыше } \\
\text { среднего } \\
\text { Above } \\
\text { Average }\end{array}$ & $\begin{array}{c}\text { Высокий } \\
\text { High }\end{array}$ \\
\hline $\begin{array}{l}\text { Обучающиеся и начина- } \\
\text { ющие специалисты пси- } \\
\text { холого-педагогического } \\
\text { направления (девушки) } \\
\text { Psychology and pedagogy } \\
\text { students and young } \\
\text { experts (girls) }\end{array}$ & 2 & 28 & 63 & 7 & 0 \\
\hline $\begin{array}{l}\text { Обучающиеся и начина- } \\
\text { ющие специалисты пси- } \\
\text { холого-педагогического } \\
\text { направления (юноши) } \\
\text { Psychology and pedagogy } \\
\text { students and young } \\
\text { experts (young men) }\end{array}$ & 3 & 35 & 48 & 11 & 3 \\
\hline $\begin{array}{l}\text { Обучающиеся по другим } \\
\text { направлениям подготов- } \\
\text { ки (девушки) } \\
\text { Students in other } \\
\text { disciplines (girls) }\end{array}$ & 5 & 30 & 43 & 21 & 1 \\
\hline $\begin{array}{l}\text { Обучающиеся по другим } \\
\text { направлениям подготов- } \\
\text { ки (юноши) } \\
\text { Students in other } \\
\text { disciplines (young men) }\end{array}$ & 11 & 30 & 30 & 22 & 7 \\
\hline
\end{tabular}


Анализируя процентные показатели количества молодежи, характеризующейся разными уровнями развития креативности, можно утверждать, что большинство молодых людей (более 1/2 каждой выборки) имеет средний уровень развития креативности. В среднем 1/6 часть выборок составляют молодые люди с низким уровнем креативности, и 1/4 часть выборок составляют молодые люди с высоким уровнем развития креативности (таблица 4).

Таблица 4.

Процентные показатели количества молодых людей, характеризующихся разными уровнями развития креативности (\%)

Table 4.

Percentage distribution of young people with various levels of creativity (\%)

\begin{tabular}{|c|c|c|c|}
\hline $\begin{array}{l}\text { Уровни развития } \\
\text { вреативности } \\
\text { Levels of Creativity } \\
\text { Samples }\end{array}$ & $\begin{array}{c}\text { Низкий } \\
\text { Low }\end{array}$ & $\begin{array}{l}\text { Cредний } \\
\text { Average }\end{array}$ & $\begin{array}{c}\text { Высокий } \\
\text { High }\end{array}$ \\
\hline $\begin{array}{l}\text { Обучающиеся и начинающие специ- } \\
\text { алисты психолого-педагогического } \\
\text { направления (девушки) } \\
\text { Psychology and pedagogy students } \\
\text { and young experts (girls) }\end{array}$ & 13 & 63 & 24 \\
\hline $\begin{array}{l}\text { Обучающиеся и начинающие специ- } \\
\text { алисты психолого-педагогического } \\
\text { направления (юноши) } \\
\text { Psychology and pedagogy students } \\
\text { and young experts (young men) }\end{array}$ & 19 & 67 & 14 \\
\hline $\begin{array}{l}\text { Обучающиеся по другим направлени- } \\
\text { ям подготовки (девушки) } \\
\text { Students in other disciplines (girls) }\end{array}$ & 15 & 59 & 26 \\
\hline $\begin{array}{l}\text { Обучающиеся по другим направлени- } \\
\text { ям подготовки (юноши) } \\
\text { Students in other disciplines (young } \\
\text { men) }\end{array}$ & 17 & 56 & 27 \\
\hline
\end{tabular}

Креативность у девушек, будущих и начинающих педагогов и психологов, отрицательно умеренно коррелирует с «добром» $\left(r_{s}=-0,319, p<0,01\right)$, и положительно слабо со «злом» $\left(r_{s}=0,207, p<0,05\right)$. Креативность у юношей, будущих и начинающих педагогов и психологов, отрицательно слабо коррелирует 
с «добром» $\left(r_{s}=-0,257, p<0,05\right)$, и не коррелирует со «злом». Креативность у девушек, обучающихся по другим направлениям подготовки, не коррелирует с «добром» и отрицательно умеренно коррелирует со «злом» $\left(r_{s}=-0,320\right.$, p < 0,01). Креативность у юношей, обучающихся по другим направлениям, коррелирует отрицательно умеренно с «добром» $\left(r_{s}=-0,378, p<0,01\right)$ и не коррелирует со «злом» (таблица 5).

Таблица 5.

Корреляционные показатели шкалы «креативность» с показателями шкал, отражающих особенности нравственного развития молодежи

Table 5.

Correlation coefficients between "creativity" and the characteristics of the moral development of young people

\begin{tabular}{|c|c|c|c|c|}
\hline $\begin{array}{l}\quad \begin{array}{r}\text { Bыборки } \\
\text { Samples }\end{array} \\
\text { Лич- } \\
\text { ност- } \\
\text { Hыe } \\
\text { чepmb } \\
\text { Personal } \\
\text { Traits }\end{array}$ & $\begin{array}{c}\text { Обучающиеся } \\
\text { и начинающие } \\
\text { специалисты } \\
\text { психолого-пе- } \\
\text { дагогического } \\
\text { направления } \\
\text { (девушки) }\end{array}$ & $\begin{array}{l}\text { Обучающиеся } \\
\text { и начинаю- } \\
\text { щие специа- } \\
\text { листы пси- } \\
\text { холого-педа- } \\
\text { гогического } \\
\text { направления } \\
\text { (юноши) }\end{array}$ & $\begin{array}{l}\text { Обучающиеся } \\
\text { по другим на- } \\
\text { правлениям } \\
\text { подготовки } \\
\text { (девушки) }\end{array}$ & $\begin{array}{c}\text { Обучающиеся } \\
\text { по другим на- } \\
\text { правлениям } \\
\text { подготовки } \\
\text { (юноши) }\end{array}$ \\
\hline $\begin{array}{l}\text { По функции } \\
\text { «добра» } \\
\text { "Good" Function }\end{array}$ & $-0,319 * *$ & $-0,257^{*}$ & $-0,196$ & $-0,378^{* *}$ \\
\hline $\begin{array}{l}\text { По функции «зла» } \\
\text { "Evil" Function }\end{array}$ & $0,207^{*}$ & 0,033 & $0,320^{* *}$ & $-0,116$ \\
\hline $\begin{array}{l}\text { Человечность } \\
\text { Humaneness }\end{array}$ & $-0,359 * *$ & $-0,225^{*}$ & $-0,335^{* *}$ & $-0,268^{*}$ \\
\hline
\end{tabular}

Примечание: ** коррелячия значима на уровне 0,01 (2-сторон.); * корреляция значима на уровне 0,05 (2-сторон.).

Note: ** Correlation is significant at the 0.01 level (2-tailed); * Correlation is significant at the 0.05 level (2-tailed).

Таким образом, корреляционные показатели шкалы «креативность» с показателями шкал, отражающих развитие нравственных качеств у молодежи, свидетельствуют о том, что чем более креативными становятся молодые люди, тем меньше у них развиты качества «добра», больше развита функция «зла» и тем меньше человечности они проявляют.

Как же объясняются такие результаты? Мы полагаем, что поскольку при актуализации креативной способности у человека появляются несколько вариантов решений, то перед ним встает необходимость совершения 
выбора в пользу одного из них. А нравственные нормы выступают теми ориентирами и границами, которые не позволяют человеку сделать ошибочный выбор. Поэтому если человек увлекся творческим подходом к делу в ущерб соблюдению нравственных норм, это является признаком того, что такая деятельность будет бесполезной или, что еще хуже, вредной с точки зрения ее влияния на развитие человеческих качеств, как в самом человеке, так и в других людях.

\section{Выводы}

Для молодых людей, избравших свой профессиональный путь в области психолого-педагогического направления, в большей мере значимо, чтобы их собственное развитие осуществлялось на основе нравственных ценностей. Иначе без этого у них не формируются профессионально значимые личностные качества, необходимые специалистам в области психологии и педагогики, т. е. гуманистических профессий. Уклонение от совершения нравственного выбора данными молодыми людьми отрицательно влияет на их личностное развитие. А это означает, что им трудно будет выполнять свою профессиональную функцию по формированию и воспитанию личности подрастающего поколения.

Таким образом, развитие таких качеств личности, как доброта и человечность, являющихся выражением нравственности личности, особенно у будущих и начинающих специалистов психолого-педагогического направления, нуждается в пристальном внимании и целенаправленно организованной работе в процессе профессиональной подготовки.

Когда у молодежи развивается человечность, то одновременно снижается креативность в понимании самоактуализирующейся личности. Получается, что зарубежная гуманистическая психология может способствовать разложению нравственно незрелых умов и душ молодежи в связи с тем, что в ней размываются, стираются и подменяются основные нравственные понятия на понятия, ориентирующие их развиваться в направлении потери человеческой сущности.

Говоря о креативности и ее развитии, необходимо понимание того, что у молодежи надо развивать креативность не в пространстве «выдумывания», «придумывания» собственных нравственных положений, а в сфере творческого поиска путей претворения общечеловеческих ценностей в жизнь, проявления своего творческого потенциала ради других людей и общества в целом, в выборе нравственных способов решения задач и проблем, воздействия и влияния, оказания помощи другим людям.

В процессе развития креативности молодежи нужно, прежде всего, оценивать все новое на соответствие требованиям нравственности 
и социальной ценности, а только затем - то, насколько это оригинально, отлично и нестандартно.

У молодежи надо развивать человечность как проявление нравственности, основывающейся на непреходящих общечеловеческих принципах. Необходимо формировать у молодых людей понимание того, что игнорирование тем нравственности, развития человечности, - есть не что иное, как пропаганда безнравственности.

\section{Литература}

1. Аверьянова Г.А. К вопросу об истории развития понятия творчества // Современные исследования социальных проблем (электронный научный журнал). - 2016. - № 3-2 (59). - C. 4-11. - URL: http://ej.soc-journal.ru/ archive/3-22016.pdf

2. Агафонова С. В. Исследование проблем нравственного развития личности в возрастном периоде «ранняя взрослость» // Ученые записки: электронный научный журнал Курского государственного университета. - 2015. - № 3 (35). - URL: http://www.scientific-notes.ru/index. php?page $=6 \&$ new $=40$

3. Агафонова С. В. Особенности связи мотивационно-волевого компонента с направленностью нравственного выбора и уровнем нравственного развития человека // Психология. Историко-критические обзоры и современные исследования. - 2015. - № 6. - С. 8-28.

4. Акмеология: Учебное пособие / А. Деркач, В. Зазыкин. - СПб.: Питер, 2003. - 256 с. - С. 20-21.

5. Асмолов А. Г. Психология личности: культурно-историческое понимание развития человека. 3-е изд., испр. и доп. - М.: Смысл, Академия, 2007. - 528 с.

6. Большой психологический словарь / Под ред. Б. Г. Мещерякова, акад. В. П. Зинченко. - М.: Прайм-ЕВРОЗНАК, 2003. - URL: http://www.psyoffice. ru/5-psychology-1001.htm

7. Брюхова Н. Г. Нравственное развитие человека в психолого-акмеологическом консультировании по проблемам жизненного пути // Научно-практический журнал «Акмеология». - 2014. - № S1-2. - С. 48-50.

8. Брюхова Н. Г. Нравственное саморазвитие человека // European Social Science Journal. - 2015. - № 7. - C. 289-301.

9. Веселова Е. К. Практические занятия в рамках программ духовно-нравственного воспитания в вузе. Методические материалы // Образовательные технологии. Технологии и практика обучения. - М., 2015. № 1. - С. 89-117.

10. Воловикова М. И. Представления русских о нравственном идеале. М: Изд-во Института психологии РАН, 2004. - 312 с. 
11. Гозман Л. Я. Самоактуализационный тест / Л. Я. Гозман, М. В. Кроз, М. В. Латинская. - М.: Рос. пед. агентство, 1995. - 43 с.

12. Еремина Л. И. Развитие креативности личности: психологический аспект // Общество: социология, психология, педагогика. - 2014. № 1. - С. 42-47.

13. Журавлев А. Л., Купрейченко А. Б. Нравственная элита в современном российском обществе: социально-психологический аспект // Психология нравственности / Отв. ред. А. Л. Журавлев, А. В. Юревич. - М.: Изд-во Института психологии РАН, 2010. - С. 209-236.

14. Ильин Е. П. Психология творчества, креативности, одаренности. - СПб.: Питер, 2009. - 434 с.

15. Красило А. И. Психологическое консультирование: проблемы, технологии:Учебное пособие. - М.: Изд-во Московского психолого-социального института; Воронеж: НПО «МОДЭК», 2007. - 504 с.

16. Маслоу А. Психология бытия. - М.: Ваклер, Рефл-бук, 1997. - 300 с.

17. Маслоу А. Г. Дальние пределы человеческой психики. - СПб.: Евразия, 1997. -430 c.

18. Мельникова Н. В. Развитие нравственной сферы личности дошкольника: дисс. ... д. психол. наук. - Курган, 2009. - 343 с.

19. Попов Л. М., Голубева О. Ю., Устин П. Н. Добро и зло в этической психологии личности. - М.: Изд-во Института психологии РАН, 2008. - 240 с.

20. Психологические исследования духовно-нравственных проблем / Отв. ред. А. Л. Журавлев, А. В. Юревич. - М.: Изд-во Института психологии $\mathrm{PAH}, 2011 .-480 \mathrm{c}$.

21. Психология профессионального роста: факторы и закономерности: монография / Н. Г. Брюхова, М. Ю. Виноградская, Н. В. Гуремина и др. Новосибирск: Изд-во ЦРНС, 2014. - С. 129-178.

22. Роджерс К. Р. Взгляд на психотерапию. Становление человека. - М.: Прогресс, 1994. - 478 с.

23. Рубинштейн С. Л. Проблемы общей психологии / Отв. ред. (и автор вступительной статьи) Е. В. Шорохова. - М.: Педагогика, 1973. - С. 373-377.

24. Сучкова Т. В. Нравственная сфера личности студентов как субъектов учебно-профессиональной деятельности: дисс. ... канд. психол. наук. Казань, 2008. - 171 с.

25. Франкл В. По ту сторону самореализации и самовыражения // Психотерапия и экзистенциализм: избранные работы по логотерапии. М.: Изд-во Института общегуманитарных исследований, 2015. - 192 с.

26. Шадриков В. Д. От индивида к индивидуальности. Введение в психологию. - М.: Изд-во Института психологии PAH, 2009. - 656 с. - URL: http://fictionbook.ru/static/trials/09/41/37/09413787.a6.pdf 
27. Юревич А. В., Ушаков Д. В. Нравственное состояние современного российского общества // Психология нравственности / Отв. ред. А. Л. Журавлев, А. В. Юревич. - М.: Изд-во Института психологии РАН, 2010. - С. 177-208. 28. Agafonova S., Bryukhova N., Kaigorodov B. Professional and personal undergraduates' development in the educational process from the perspective of competency-based approach // Procedia - Social and Behavioral Sciences. 2015. - V. 214. - pp. 479-486. DOI: 10.1016/j.sbspro.2015.11.732

29. Barnett M. D., Deutsch J. T. Humanism, authenticity, and humor: Being, being real, and being funny // Personality and Individual Differences. - 2016. V. 91. - pp. 107-112. DOI: 10.1016/j.paid.2015.12.004

30. Duff J., Rubenstein C., Prilleltensky I. Wellness and fairness: Two core values for humanistic psychology // Humanistic Psychologist. - 2016. - V. 44. I. 2. - pp. 127-141. DOI: 10.1037/hum0000020

31. Frankl V. The Will to Meaning: Foundations and Applications of Logotherapy // Psychotherapy and Existentialism. Selected Papers on Logotherapy. New York: Plume press, 1969. - 181 p.

32. Heffernan G. The Phenomenon Happiness: Prolegomena to a Phenomenological Description // Humanistic Psychologist. - 2014. - V. 42. - I. 3. pp. 249-267. DOI: 10.1080/08873267.2014.929873

33. Helminiak D. A. Advocating truth but respecting diversity: Resolving the contemporary "paradox" // Humanistic Psychologist. - 2016. - V. 44. - I. 4. pp. 355-365. DOI: 10.1037/hum0000040

34. Koydemir S., Şimşek Ö. F., Demir M. Pathways from Personality to Happiness: Sense of Uniqueness as a Mediator // Journal of Humanistic Psychology. 2014. - V. 54. - I. 3. - pp. 314-335. DOI: 10.1177/0022167813501226

35. Lemberger M. E., Lemberger-Truelove T. L. Bases for a More Socially Just Humanistic Praxis // Journal of Humanistic Psychology. - 2016. - V. 56. I. 6. - pp. 571-580. DOI: 10.1177/0022167816652750

36. Maslow A. H. Motivation and Personality. - New York: Harper \& Bros., 1954 (Rev. ed., 1970). - 411 p.

37. Robbins B. D. The Heart of Humanistic Psychology: Human Dignity Disclosed Through a Hermeneutic of Love // Journal of Humanistic Psychology. 2015. - V. 56. - I. 3. - pp. 223-237. DOI: 10.1177/0022167815591408

38. Rogers C. Freedom to learn: a view of what education might become. Columbus, $\mathrm{OH}$ : Charles Merrill, 1969. - 358 p.

\section{References}

1. Aver'yanova G. A. On the issue of the history of the concept of creativity. Modern Research of Social Problems, 2016, no. 3-2 (59), pp. 4-11. Available at: http://ej.soc-journal.ru/archive/3-22016.pdf 
2. Agafonova S. V. Studying the problems of the person's moral development in young adulthood. Scientific Notes: The Online Academic Journal of Kursk State University, 2015, no. 3 (35). Available at: http://www.scientific-notes. ru/index.php?page $=6 \&$ new $=40$

3. Agafonova S. V. The association among the motivational and volitional component, a moral choice orientation, and the level of moral development of the person. Psikhologiya. Istoriko-kriticheskie obzory i sovremennye issledovaniya - Psychology. Historical-critical Reviews and Current Researches, 2015, no. 6, pp. 8-28 (in Russian).

4. Derkach A., Zazykin V. Akmeologiya [Acmeology]. St. Petersburg, Piter Publ., 2003. 256 p.

5. Asmolov A. G. Psikhologiya lichnosti: kul'turno-istoricheskoe ponimanie razvitiya cheloveka [Personality psychology: Cultural-historical understanding of human development]. Moscow, Smysl, Akademiya Publ., 2007. 528 p.

6. Meshcheryakov B. G., Zinchenko V. P. (ed.) Bol'shoi psikhologicheskii slovar' [Great psychological dictionary]. Moscow, 2003. Available at: http:// www.psyoffice.ru/5-psychology-1001.htm

7. Bryukhova N. G. A person's moral development in psychological and acmeological counseling in life issues. Nauchno-prakticheskii zhurnal "Akmeologiya» - "Acmeology": Scientific-Practical Magazine, 2014, no. S1-2, pp. 48-50 (in Russian).

8. Bryukhova N. G. A person's moral self-development. European Social Science Journal, 2015, no. 7, pp. 289-301 (in Russian).

9. Veselova E. K. Practical studies in spiritual and moral education at the institute of higher education: Methodical materials. Educational Technology. Techniques and Practice of Training, Moscow, 2015, no. 1, pp. 89-117 (in Russian).

10. Volovikova M. I. Predstavleniya russkikh o nravstvennom ideale [Russians' ideas about the moral ideal]. Moscow, Institute of Psychology RAS Publ., 2004. 312 p.

11. Gozman L. Ya. Samoaktualizatsionnyi test [Self-actualization test]. Moscow, Ros. ped. agentstvo Publ., 1995. 43 p.

12. Eremina L. I. Developing a person's creativity: a psychological aspect. Obshchestvo: sotsiologiya, psikhologiya, pedagogika - Society: sociology, psychology, pedagogics, 2014, no. 1, pp. 42-47 (in Russian).

13. Zhuravlev A. L., Kupreichenko A. B. Moral elite in modern Russian society: a socio-psychological aspect. In: Psikhologiya nravstvennosti [Morals psychology]. Moscow, Institute of Psychology RAS Publ., 2010, pp. 209-236.

14. Il'in E. P. Psikhologiya tvorchestva, kreativnosti, odarennosti [Psychology of creativity and giftedness]. St. Petersburg, Piter Publ., 2009. 434 p. 
15. Krasilo A. I. Psikhologicheskoe konsul'tirovanie: problemy, tekhnologii: Uchebnoe posobie [Psychological counseling: issues and techniques]. Moscow, Moscow Psychological and Social Institute Publ., 2007. 504 p.

16. Maslow A. Toward a Psychology of Being. Litton Education Publishing, 1968. (Russ. ed.: Maslou A. Psikhologiya bytiya. Moscow, Vakler, Refl-buk Publ., 1997. 300 p.).

17. Maslow A. The Farther Reaches of Human Nature. Harmondsworth: Penguin, 1971. (Russ. ed.: Maslou A. G. Dal'nie predely chelovecheskoi psikhiki. St. Petersburg, Evraziya Publ., 1997. 430 p.).

18. Mel'nikova N. V. Razvitie nravstvennoi sfery lichnosti doshkol'nika [Developing the moral sphere of a preschool child's personality]. Diss. Dr. Sci. (Psych.). Kurgan, 2009. 343 p.

19. Popov L. M., Golubeva O. Yu., Ustin P. N. Dobro i zlo v eticheskoi psikhologii lichnosti [Good and evil in the ethical psychology of personality]. Moscow, Institute of Psychology RAS Publ., 2008. 240 p.

20. Zhuravlev A. L., Yurevich A. V. (ed.) Psikhologicheskie issledovaniya dukhovnonravstvennykh problem [Psychological studies of spiritual and moral issues]. Moscow, Institute of Psychology RAS Publ., 2011. 480 p.

21. Bryukhova N. G., Vinogradskaya M. Yu., Guremina N. V. Psikhologiya professional'nogo rosta:faktory izakonomernosti [Psychology of professional growth: factors and principles]. Novosibirsk, CRNS Publ., 2014, pp. 129-178.

22. Rogers C. On Becoming a Person: A Therapists View of Psychotherapy. Boston, 1961. (Russ. ed.: Rodzhers K. R. Vzglyad na psikhoterapiyu. Stanovlenie cheloveka. Moscow, Progress Publ., 1994. 478 p.).

23. Rubinshtein S. L. Problemy obshchei psikhologii [The problems of general psychology]. Moscow, Pedagogika Publ., 1973, pp. 373-377.

24. Suchkova T. V. Nravstvennaya sfera lichnosti studentov kak sub"ektov uchebnoprofessional'noi deyatel'nosti [The moral sphere of students as subjects of educational and professional activity]. Diss. Cand. Sci. (Psych.). Kazan, 2008. 171 p.

25. Frankl V. On the other side of self-realization and self-expression. In: Psikhoterapiyaiekzistentsializm:izbrannye raboty pologoterapii [Psychotherapy and existentialism: selected works in logotherapy]. Moscow, Institute for Humanities Research Publ., 2015. 192 p.

26. Shadrikov V. D. Ot individa k individual'nosti. Vvedenie v psikhologiyu [From an individual to individuality: An introduction to psychology]. Moscow, Institute of Psychology RAS Publ., 2009. 656 p. Available at: http://fictionbook.ru/ static/trials/09/41/37/09413787.a6.pdf

27. Yurevich A. V., Ushakov D. V. Moral state of modern Russian society. In: Psikhologiya nravstvennosti [Morals psychology]. Moscow, Institute of Psychology RAS Publ., 2010, pp. 177-208. 
28. Agafonova S., Bryukhova N., Kaigorodov B. Professional and personal undergraduates' development in the educational process from the perspective of competency-based approach. Procedia - Social and Behavioral Sciences, 2015, V. 214, pp. 479-486. DOI: 10.1016/j.sbspro.2015.11.732

29. Barnett M. D., Deutsch J.T. Humanism, authenticity, and humor: Being, being real, and being funny. Personality and Individual Differences, 2016, V. 91, pp. 107-112. DOI: 10.1016/j.paid.2015.12.004

30. Duff J., Rubenstein C., Prilleltensky I. Wellness and fairness: Two core values for humanistic psychology. Humanistic Psychologist, 2016, V. 44, I. 2, pp. 127-141. DOI: 10.1037/hum0000020

31. FrankIV. The Will to Meaning: Foundations and Applications of Logotherapy. Psychotherapy and Existentialism. Selected Papers on Logotherapy. New York, Plume press, 1969. $181 \mathrm{p}$.

32. Heffernan G. The Phenomenon Happiness: Prolegomena to a Phenomenological Description. Humanistic Psychologist, 2014, V. 42, I. 3, pp. 249-267. DOI: 10.1080/08873267.2014.929873

33. Helminiak D. A. Advocating truth but respecting diversity: Resolving the contemporary "paradox". Humanistic Psychologist, 2016, V. 44, I. 4, pp. 355-365. DOI: 10.1037/hum0000040

34. Koydemir S., Şimşek Ö. F., Demir M. Pathways from Personality to Happiness: Sense of Uniqueness as a Mediator. Journal of Humanistic Psychology, 2014, V. 54, I. 3, pp. 314-335. DOI: 10.1177/0022167813501226

35. Lemberger M. E., Lemberger-Truelove T. L. Bases for a More Socially Just Humanistic Praxis. Journal of Humanistic Psychology, 2016, V. 56, I. 6, pp. 571-580. DOI: 10.1177/0022167816652750

36. Maslow A. H. Motivation and Personality. New York, Harper \& Bros., 1954 (Rev. ed., 1970). 411 p.

37. Robbins B. D. The Heart of Humanistic Psychology: Human Dignity Disclosed Through a Hermeneutic of Love. Journal of Humanistic Psychology, 2015, V. 56, I. 3, pp. 223-237. DOI: 10.1177/0022167815591408

38. Rogers C. Freedom to learn: a view of what education might become. Columbus, $\mathrm{OH}$, Charles Merrill, 1969. 358 p. 